\title{
Management of Meloidogyne incognita Infecting Eggplant Using Moringa Extracts, Vermicompost, and Two Commercial Bio-products
}

\author{
Khairy, Doaa ; A.R.Refaei and Fatma A.M.Mostafa \\ Agric. Zool. Dept., Fac. Agric., Mansoura Univ., Mansoura,Egypt \\ Corresponding author email:doaakhairy13@yahoo.com
}

\begin{abstract}
Two greenhouse pot experiments were conducted to assess the effectiveness of dried leaf powder and extractives (ethanolic, and aqueous extracts) of Moringa (Moringa oleifera) or organic fertilizer (vermicompost) and two commercial products namely BioNematon (Purpureocillium lilacinum) and Abamectin, Gold (Streptomyces avermitilis) on eggplant growth parameters and Meloidogyne incognita infection. In both experiments observed data revealed that combined applications showed better performance than did single ones. Eggplant growth parameters in terms of fresh shoot and root lengths, and shoot and root weights were remarkably improved with single application of Abamectin or BioNematon followed by plant extracts or vermicompost resulting in a significant $(\mathrm{P}<0.05)$ suppression in nematode population in soil and root as well as the number of galls and egg masses. However, the potential of bioagent was increased with the addition of Moringa leaf powder and significantly $(\mathrm{P}<0.05)$ enhanced eggplant growth and suppressed nematode population, root galling and female fecundity even no significant differences were recorded compared to Oxamyl. Vermicompost derived from municipal wastes showed a low $\mathrm{C} / \mathrm{N}$ ratio $(1: 14)$ with an excess of nitrogen that exhibited nematicidal activity against M.incognita. The addition of vermicompost with such bio-agents showed a synergistic effect upon nematode population, root galling and number of females. Significant differences whether in plant growth or nematode reproduction were not detected compared to Oxamyl. Thus the current study revealed the potential of leaf powder and extractives of Moringa, vermicompost, P.lilacinum and S.avermitilis as safe alternatives to control M.incognita infecting eggplant through an integrated management program and bring sustainability to agriculture.
\end{abstract}

Keywords: Streptomyces avermitilis, Purpureocillium lilacinum, Vermicompost, Meloidogyne incognita.

\section{INTRODUCTION}

Eggplant is a major fruit vegetable crop with global production in 2018 exceeding 52 million tonnes (FAOSTAT, 2019).Root-knot nematodes, Meloidogyne spp. are considered one of the most important pathogens causing substantial damage to eggplants grown in tropical and subtropical regions (Hussain et al., 2015). The use of nematicides is the most desirable method for the management of root-knot nematodes. However, their adverse effects on the environment, ground water, soil texture, human, 
plant and animal health (Meyer, 2003), led scientists to search for ecofriendly alternatives strategies. Among these strategies plant extractives that have been shown nematicidal properties against root-knot nematodes, Meloidogyne spp. under greenhouse and field conditions and their potential for use in nematode control programs has been suggested (Ismail, 2013; Sowley et al., 2018 ; Mainoo and Banful, 2019; El Deriny et al., 2020).

Another possible alternative is the use of vermicompost which is particularly interesting because of its low cost and positive effect on plant growth, physical, chemical, and biological properties of the soils (Arancon et al., 2005; Gabour et al., 2015). Vermicomposting is a mesophilic process utilizing earthworms to turn the organic waste material into high-quality compost known as vermicompost that consists mainly of worm cast in addition to decayed organic matter (Devi and Prakash 2015; Mohamed et al., 2019). Vermicompost has been found to have beneficial effects when used as soil amendments in field studies (Pathma and Sakthivel, 2012; Mohamed et al., 2019). In particular, the suppressive effect of vermicompost on plantparasitic nematodes was documented (Singh and Prasad, 2014; Gabour et al., 2015; Mohamed et al., 2019).

Bacteria and fungi are the most important biocontrol agents that have been studied. For instance, Abamectin a natural fermentation product of the bacterium Streptomyces avermitilis was reported to have nematicidal activity against different genera of plant nematodes (Youssef and Lashein, 2015; Sasanelli et al., 2019). The common soil fungus, Purpureocillium lilacinum (Formerly Paecilomyces lilacinus) is well known as a facultative egg pathogen of sedentary nematodes. Its nematicidal activity against different plant nematodes was documented (Pura and Matiyar, 2016; Ganaie, 2018; Metwally et al. 2019).

The objective of this research was to explore the impact of Moringa plant extracts, granular vermicompost integrated with two commercial biocontrol agents on $M$. incognita infection and eggplant growth response.

\section{MATERIALS AND METHODS}

\section{Moringa leaf extracts}

\section{Moringa leaf powder}

Fresh leaves of Moringa (Moringa oleifera Lam, Fam: Moringaceae) were collected, washed by distilled water and air dried under room temperature $\left(25-27^{\circ} \mathrm{C}\right)$. Leaves were then crushed and screened by a specific mesh sieve to get the moringa powder. Moringa leaf powder samples were then stored in a sterilized bag.

\section{Ethanolic leaf extract}

Moringa powder $(0.4 \mathrm{~g})$ was soaked in $100 \mathrm{ml}$ of the selected solvent (ethanol $95 \%$ ) for two hours. Solutions were then centrifuged at $2000 \mathrm{rpm}$ for ten minutes and filtered through Whatman No.1 filter paper.

\section{Aqueous leaf extract}

Twenty-five grams of thoroughly washed and chopped fresh leaves of moringa were ground separately in an electric blender in $100 \mathrm{ml}$ of distilled water. Solutions were 
then centrifuged at $5000 \mathrm{rpm}$ for five minutes and filtered through Whatman No. 1 filter paper.

\section{Vermicompost}

An organic fertilizer which was brought from Olive Research Department, Horticultural Research Institute, Giza, Egypt.

3.Commercial bio-products

1.BioNematon ${ }^{\circledR} 1.15 \%$ WP, a commercial product of Purpureocillium lilacinum which contains $1 \times 10^{8} \mathrm{cfu} / \mathrm{g}$ of fungus. A solution of $2.5 \mathrm{~g} / 100 \mathrm{ml}$ distilled water was prepared.

2.Gold (Abamectin)® $1.8 \%$ EC, a commercial product of Streptomyces avermitilis which contains $1 \times 10^{8} \mathrm{cfu} / \mathrm{g}$ of bacterium. Abamectin was added at a concentration of 400ppm (0.4 ml Abamectin/ 1000ml distilled water).

4. Nematicide

Oxamyl: (Vydate $10 \%$ G.) Methyle - N - N - dimethyl - (N (methyle) carbomycocyl) -1- hioxamidate,

\section{Experimental Design}

A.Impact of Moringa leaf extractives and two bio-products on Meloidogyne incognita infecting eggplant

Seedlings of eggplant cv. Black king (30 days old) were separately transplanted in plastic pots (13 cm-diam) filled with $850 \mathrm{~g}$ steam sterilized clay loamy soil ( Coarse sand 1.90; Fine sand 26.5; Silt 32.6 ; Clay 36.5 ). Five days after transplanting, seedlings were inoculated with approximately 1500 eggs of $M$. incognita. Five days later Moringa extracts (Aqueous and Ethanolic extracts) as well as dried leaf powder were introduced to soil pots. Aqueous and Ethanolic extracts of Moringa were applied as a soil drench at the concentration of $5 \mathrm{ml} /$ pot. Moringa leaf powder was incorporated into the soil at the rate of $5 \mathrm{~g} / \mathrm{pot}$. Simultaneously, the commercial biocide, Gold $1.8 \%$ EC (Abamectin) or BioNematon were applied singly and in combination. All pots were slightly irrigated following treatments. The conventional nematicide, Oxamyl was applied at the recommended rate $(0.3 \mathrm{~g} / \mathrm{pot})$ two days after nematode inoculation for comparison. Pots free of nematode inoculum were served as a negative control, however, those received nematode inoculum served as the positive control. Each treatment was replicated four times. All plastic pots were irrigated with water as needed and arranged in a randomized-complete block design (RCBD) and agronomically treated the same under green house conditions.

Treatments were as follows: 1-Moringa leaf powder (MP); 2- Ethanolic extract of Moringa (EM); 3-Aqueous extract of Moringa(AM); 4-Gold (Abamectin, S.avermitilis) (G); 5-BioNematon; 6-Moringa leaf powder + Gold(MP+G); 7Ethanolic extract of Moringa + Gold $(\mathrm{EM}+\mathrm{G}) ; 8$-Aqueous extract of Moringa + Gold $(\mathrm{AM}+\mathrm{G})$; 9-Moringa leaf powder+ BioNematon(MP+BN); 10-Ethanolic extract of 
Moringa + BioNematon $(\mathrm{EM}+\mathrm{BN})$; 11-Aqueous extract of Moringa+ BioNematon $(\mathrm{AM}+\mathrm{BN})$; 12-Oxamyl $(\mathrm{O})$; 13-Plant free of Nematode and 14-Nematode only.

B.Impact of vermicompost and two bio-products on Meloidogyne incognita infecting eggplant

The same protocol as outlined before was repeated using vermicompost. Treatments were as follows: 1-Vermicompost (VC); 2-Gold (Abamectin) (G) 3-BioNematon(BN); 4- Vermicompost +BioNematon $(\mathrm{VC}+\mathrm{BN})$; 5- Vermicompost + Gold ( $\mathrm{VC}+\mathrm{G})$; 6Oxamyl (O); 7- Plant free of Nematode and 8- Nematode only.

For both experiments, fifty five days after nematode inoculation, plants were harvested. Data on growth performance (length and fresh weight of shoots, root as well as shoot dry weight) were recorded. Second stage juveniles of $M$. incognita were extracted from soil using sieving and modified Baermann-technique according to Goodey (1957) and counted. Roots were stained in acid fuchsin lactic acid (Byrd et al., 1983), washed in tap water and placed in pure cold glycerin. Numbers of galls, egg masses, females, and development stages were determined with the aid of a stereomicroscope and recorded. The root-knot nematode reproduction (Rf) was calculated. Root gall (RGI) index was determined according to the scale given by Taylor and Sasser (1978).

\section{Biochemical Analysis of Moringa extractives}

The aqueous and ethanolic extracts of M.oleifera were separately screened for the presence of bioactive constituents using standard phytochemical techniques as described by Arefin et al. (2015) Ashtalakshmi and Prabakaran (2015) and Usharani et al. (2016).

\section{Flavonoids}

The presence of flavonoids in Moringa extracts was detected according to the method of Arefin et al. (2015). One $\mathrm{ml}$ Moringa extract of each investigated sample was treated with few drops of $10 \%\left(\mathrm{CH}_{3} \mathrm{COO}\right)_{2} \mathrm{~Pb}$. The presence of yellow precipitate affirms the presence of flavonoids.

\section{Saponins}

The presence of saponins was detected according to the method of Arefin et al. (2015). One $\mathrm{ml}$ Moringa extract of each investigated sample was added to five $\mathrm{ml}$ of distilled water and well shaked. The appearance of foam measuring about one $\mathrm{cm}^{3}$ indicates the presence of saponins.

\section{Tannins}

The presence of tannins was examined by the method detailed by Usharani et al. (2016). One $\mathrm{ml}$ of Moringa extract of each investigated sample was added to five $\mathrm{ml}$ of distilled water and placed for boiling in a hot water bath for $5 \mathrm{~min}$. Then the samples were cooled down at room temperature and few drops of $5 \% \mathrm{FeCL}_{3}$ solution were added. The appearance of brownish green colour confirms the occurrence of tannins. 


\section{Phenols}

The presence of phenols was examined by the method detailed by Usharani et al. (2016). Few drops of 5\% $\mathrm{FeCL}_{3}$ solution were added to two ml Moringa extract of each investigated sample. Presence of dark green colour emphasizes the existence of phenols.

Glycosides

The presence of glycosides was detected using Molish's reagent according to Ashtalakshmi and Prabakaran (2015). Two ml Moringa extract of each investigated sample were added to one $\mathrm{ml}$ of Molish's reagent followed by one $\mathrm{ml}$ of Conc. $\mathrm{H}_{2} \mathrm{SO}_{4}$ along the wall of the test tube. Formation of purple ring at the intersection of two liquids indicates the presence of glycosides.

\section{Data analysis}

All the obtained results were subjected to analysis of variance (ANOVA) followed by Duncan multiple range tests to compare means (Duncan, 1955). The least significant differences (LSD) at the 5\% level of probability were determined using a computer program CoStat Version.

\section{RESULTS AND DISCUSSION}

Integrated control is a sustainable approach for to the management of plantparasitic nematodes. The root-knot nematode, $M$. incognita caused a significant decrement in plant growth parameters with a reduction percentage in plant length and total plant fresh weight reached 21.6 and $39.6 \%$, respectively.(Table 1).Individual application of BioNematon (commercial product of egg parasitic fungi Purpureocillium lilacinum) and Gold (commercial product of the soil bacterium Streptomyces avermitilis surpassed Moringa plant extracts and showed the best augmentation in plant length, total plant fresh weight and shoot dry weight (Table1) and significantly suppressed nematode population, number of females, galls and egg masses compared to untreated plants (Table 2). These results support the findings of Oclarit and Cumagun ,2009; Metwally et al., 2019; Sasanelli et al., 2019). BioNematon suppressed nematode population through colonization on roots as well as on egg mass and female body, thereby destroying females, and eggs of Meloidogyne spp. (Cardona and Leguizamon, 1997; Azam et al., 2013). The enzymes i.e. protease and chitinase produced by P. lilacinum (Khan et al., 2006) are indeed effective in hyphal penetration through the cuticle of juveniles and females of $M$. javanica. Moreover, Streptomyces avermitilis can produce secondary metabolites that showed nematicidal activity against root-knot nematodes in a large number of crops under different conditions (Khalil, 2013; Metwally et al., 2019).

Moringa oleifera (Lam) leaves are rich in important minerals as Calcium, Manganese, Potassium, Iron, Zink, Phosphorous,Copper Magnesium, Sulphur and Sodium which lead to an increase in plant growth, yield (Olajide et al., 2018). In the present investigation Moringa plant extracts showed no phytotoxicity to eggplant infected with M.incognita. Moringa powder leaf was superior in enhancing plant growth attributes i.e. shoot length and shoot fresh weight followed by aqueous leaf extract then ethanolic extract (Table 1). This confirmed the report by Sowley et al. (2013) that application rates of Moringa leaf powder increased sweet pepper plant 
growth and yield and decreased nematode population indicating their potential in the management of root-knot nematodes. Powdered leaves of moringa may change the physical structure and soil fertility resulting in increased tolerance of the plants to nematode attack (Mahmood and Saxena, 1992). The presence of cytokinin group in the ethanolic extract of Moringa leaves influenced height in sweet pepper plants (Makkar and Becker,1996).

Table1: Combined effect of Moringa extracts and Gold (Abamectin) or BioNematon on growth of eggplant infected with Meloidogyne incognita.

\begin{tabular}{|c|c|c|c|c|c|c|c|c|}
\hline \multirow[b]{2}{*}{ Treatments } & \multicolumn{8}{|c|}{ Plant Growth Response } \\
\hline & $\begin{array}{l}\text { Shoot } \\
\text { Length } \\
(\mathrm{cm})\end{array}$ & $\begin{array}{l}\text { Plant } \\
\text { Length } \\
(\mathrm{cm})\end{array}$ & $\begin{array}{c}\text { Inc. } \\
\%\end{array}$ & $\begin{array}{c}\text { Shoot } \\
\text { Fresh } \\
\text { weight } \\
(\mathrm{g})\end{array}$ & $\begin{array}{c}\text { Plant } \\
\text { Fresh } \\
\text { weight } \\
(\mathrm{g})\end{array}$ & $\begin{array}{c}\text { Inc. } \\
\%\end{array}$ & $\begin{array}{c}\text { Shoot } \\
\text { Dry } \\
\text { weight } \\
(\mathrm{g})\end{array}$ & Inc.\% \\
\hline MP & $24.5 \mathrm{a}-\mathrm{c}$ & 38.8 & 9.9 & $5.8 \mathrm{a}-\mathrm{e}$ & 8.3 & 23.9 & $1.4 \mathrm{a}-\mathrm{c}$ & 27.3 \\
\hline EM & $23.8 \mathrm{~b}-\mathrm{d}$ & 35.8 & 1.4 & $4.8 \mathrm{c}-\mathrm{e}$ & 7.3 & 9.0 & $1.4 \mathrm{a}-\mathrm{c}$ & 27.3 \\
\hline AM & $23.0 \mathrm{~cd}$ & 36.0 & 2.0 & $5.4 \mathrm{a}-\mathrm{e}$ & 8.0 & 19.4 & $1.3 \mathrm{a}-\mathrm{c}$ & 18.2 \\
\hline G & $23.7 b-d$ & 39.4 & 11.6 & $6.8 \mathrm{ab}$ & 10.3 & 53.7 & $1.4 \mathrm{a}-\mathrm{c}$ & 27.3 \\
\hline $\mathrm{BN}$ & $26.0 \mathrm{ab}$ & 42.3 & 19.8 & $6.6 \mathrm{ab}$ & 10.6 & 58.2 & $1.4 \mathrm{a}-\mathrm{c}$ & 27.3 \\
\hline $\mathrm{MP}+\mathrm{G}$ & $24.7 \mathrm{a}-\mathrm{c}$ & 43.0 & 21.8 & $5.4 \mathrm{a}-\mathrm{e}$ & 10.9 & 62.7 & $1.2 \mathrm{bc}$ & 9.1 \\
\hline $\mathrm{EM}+\mathrm{G}$ & $26.0 \mathrm{ab}$ & 42.2 & 19.5 & $5.8 \mathrm{a}-\mathrm{e}$ & 10.6 & 58.2 & $1.2 \mathrm{bc}$ & 9.1 \\
\hline $\mathrm{AM}+\mathrm{G}$ & $25.3 \mathrm{a}-\mathrm{c}$ & 41.6 & 17.8 & $6.6 \mathrm{ab}$ & 11.0 & 64.2 & $1.3 \mathrm{a}-\mathrm{c}$ & 18.2 \\
\hline $\mathrm{MP}+\mathrm{BN}$ & $24.3 \mathrm{a}-\mathrm{c}$ & 45.0 & 27.5 & $5.7 \mathrm{a}-\mathrm{e}$ & 11.3 & 68.7 & $1.3 \mathrm{a}-\mathrm{c}$ & 18.2 \\
\hline $\mathrm{EM}+\mathrm{BN}$ & $25.0 \mathrm{a}-\mathrm{c}$ & 41.0 & 16.1 & $5.9 \mathrm{a}-\mathrm{e}$ & 10.8 & 61.2 & $1.3 \mathrm{a}-\mathrm{c}$ & 18.2 \\
\hline $\mathrm{AM}+\mathrm{BN}$ & $25.3 \mathrm{a}-\mathrm{c}$ & 41.3 & 17.0 & $5.5 \mathrm{a}-\mathrm{e}$ & 10.6 & 58.2 & $1.7 \mathrm{a}$ & 54.5 \\
\hline $\mathrm{O}$ & $22.3 \mathrm{~cd}$ & 36.8 & 4.2 & $5.2 b-e$ & 8.4 & 25.4 & $1.3 \mathrm{a}-\mathrm{c}$ & 18.2 \\
\hline Healthy Plants & $27.7 \mathrm{a}$ & 45.0 & 27.5 & $7.5 \mathrm{a}$ & 11.1 & 65.7 & $1.5 \mathrm{ab}$ & 36.4 \\
\hline Nematode only $(\mathrm{N})$ & $20.5 \mathrm{~d}$ & 35.3 & --- & $4.2 \mathrm{de}$ & 6.7 & --- & $1.1 \mathrm{c}$ & --- \\
\hline
\end{tabular}

Each value is the mean of four replicates. MP= Moringa leaf powder; EM= Ethanol extract of Moringa; $\mathrm{AM}=$ Aqueous extract of Moringa $\mathrm{G}=$ Gold (Abamectin Streptomyces avermitilis); $\mathrm{BN}=$ BioNematon Purpureocillium lilacinum; $\mathrm{O}=. \mathrm{Oxamyl} ; \mathrm{N}=1500$ eggs of $M$. incognita.

Means in each column followed by the same letter (s) did not differ at $\mathrm{P}<0.05$ according to Duncan multiple- range test.

Hence, in dual applications a synergistic impact on eggplant growth in terms of fresh shoot and root lengths, total plant fresh weight was induced with various degrees as compared with a single application. A pronounced improvement in shoot length was recorded with the mixture of powder extract of Moringa (MP) and Abamectin (G) or Moringa (MP) with BioNematon with percentages of increase in plant length amounted to $21.8 \& 27.5 \%$, respectively. Similar trend was noticed with 
shoot fresh weight with percentages of increase in total plant fresh weight amounted to $62.7 \& 68.7 \%$, respectively.

Table 2: Combined effect of Moringa extracts and Gold (Abamectin) or BioNematon on Meloidogyne incognita population and reproduction on eggplant.

\begin{tabular}{|c|c|c|c|c|c|c|c|c|}
\hline \multirow{3}{*}{ Treatments } & \multicolumn{3}{|c|}{ Nematode population in } & \multirow{3}{*}{$\begin{array}{c}\text { Total } \\
\text { nematode } \\
\text { population }\end{array}$} & \multirow[t]{3}{*}{ Red \% } & \multirow[t]{3}{*}{$\mathrm{Rf}^{*}$} & \multirow[t]{3}{*}{ No.galls } & \multirow[t]{3}{*}{ RGI** } \\
\hline & \multicolumn{2}{|c|}{ Root } & \multirow[t]{2}{*}{ Soil } & & & & & \\
\hline & D.S & Females & & & & & & \\
\hline MP & $3.8 \mathrm{~b}$ & $9.5 \mathrm{~b}$ & $1364.8 \mathrm{~b}$ & 1378.1 & 53.0 & 0.9 & $12.8 \mathrm{~b}$ & 2.5 \\
\hline EM & $2.5 b$ & $6.8 \mathrm{~b}$ & $958.8 \mathrm{~b}-\mathrm{d}$ & 968.1 & 67.0 & 0.6 & $8.5 \mathrm{~b}$ & 2.3 \\
\hline $\mathrm{AM}$ & $2.8 \mathrm{~b}$ & $6.3 \mathrm{~b}$ & $1231.0 \mathrm{bc}$ & 1240.1 & 57.7 & 0.8 & $8.0 \mathrm{~b}$ & 2.3 \\
\hline G & $2.3 b$ & $5.3 \mathrm{~b}$ & $820.0 \mathrm{c}-\mathrm{e}$ & 827.6 & 71.8 & 0.5 & $7.3 \mathrm{~b}$ & 2.3 \\
\hline $\mathrm{BN}$ & $2.3 \mathrm{~b}$ & $6.7 \mathrm{~b}$ & $718.3 \mathrm{c}-\mathrm{e}$ & 727.3 & 75.2 & 0.5 & $8.0 \mathrm{~b}$ & 2.3 \\
\hline $\mathrm{MP}+\mathrm{G}$ & $3.3 b$ & $6.0 \mathrm{~b}$ & $743.3 \mathrm{c}-\mathrm{e}$ & 752.6 & 74.4 & 0.5 & $8.3 \mathrm{~b}$ & 2.3 \\
\hline $\mathrm{EM}+\mathrm{G}$ & $2.3 b$ & $3.7 \mathrm{~b}$ & $430.0 \mathrm{~d}-\mathrm{f}$ & 436.0 & 85.1 & 0.3 & $5.3 \mathrm{~b}$ & 2.0 \\
\hline $\mathrm{AM}+\mathrm{G}$ & $2.3 b$ & $4.3 \mathrm{~b}$ & $712.3 \mathrm{de}$ & 718.9 & 75.5 & 0.4 & $4.7 \mathrm{~b}$ & 1.8 \\
\hline $\mathrm{MP}+\mathrm{BN}$ & $2.0 \mathrm{~b}$ & $4.7 \mathrm{~b}$ & 695.0de & 701.7 & 76.1 & 0.5 & $6.7 \mathrm{~b}$ & 2.3 \\
\hline $\mathrm{EM}+\mathrm{BN}$ & $0.8 \mathrm{~b}$ & $3.0 \mathrm{~b}$ & $478.3 \mathrm{~d}-\mathrm{f}$ & 482.1 & 83.6 & 0.3 & $3.3 \mathrm{~b}$ & 2.0 \\
\hline $\mathrm{AM}+\mathrm{BN}$ & $0.3 b$ & $3.7 \mathrm{~b}$ & 680.0de & 684.0 & 76.7 & 0.5 & $5.3 \mathrm{~b}$ & 2.0 \\
\hline $\mathrm{O}$ & $2.3 \mathrm{~b}$ & $1.3 \mathrm{~b}$ & $348.8 \mathrm{ef}$ & 352.4 & 88.0 & 0.2 & $1.5 \mathrm{~b}$ & 1.0 \\
\hline $\begin{array}{l}\text { Nematode } \\
\text { only }(\mathrm{N})\end{array}$ & $18.0 \mathrm{a}$ & $40.0 \mathrm{a}$ & $2875.0 \mathrm{a}$ & 2933.0 & ----- & 2.0 & $55.5 \mathrm{a}$ & 2.8 \\
\hline
\end{tabular}

Each value is the mean of four replicates. MP= Moringa leaf powder $\quad$ EM= Ethanol extract of Moringa $\quad \mathrm{AM}=$ Aqueous extract of Moringa $; \quad \mathrm{G}=$ Gold (Abamectin) Streptomyces avermitilis $\mathrm{BN}=$ BioNematon Purpureocillium lilacinum ; $\mathrm{O}=$. Oxamyl $(10 \% \mathrm{G}) ; \mathrm{N}=1500$ eggs of $M$. incognita . $* \mathrm{Rf}=$ Reproduction factor $=$ Final population $(\mathrm{Pf}) /$ Initial population $(\mathrm{Pi})$.

**Root gall index (RGI) was determined according to the scale given by Taylor\& Sasser (1978) as follows $0=$ no galls; $1=1-2 ; 2=3-10 ; 3=11-30 ; 4=31-100$ and $5=$ more than 100 galls.

Means in each column followed by the same letter (s) did not differ at $\mathrm{P}<0.05$ according to Duncan multiple- range test.

Soil nematode population, root galling and the number of females of M.incognita were significantly suppressed $(\mathrm{p}<0.05)$ by all plant extracts of Moringa compared to untreated plants (Table 2). However, ethanolic leaf extract of moringa being the most effective in reducing soil nematode population, number of females and root galling followed by aqueous extract as well as moringa leaf powder even no significant differences in nematode parameters among plant extracts were indicated. According to Claudius-Cole et al. (2010) and Youssef et al. (2014) reports, M. oleifera leaves contain nematicidal properties that inhibit nematode egg hatching and juvenile 
survival which may have resulted in increased plant growth parameters in treated plants. The nematicidal effect of the Moringa leaf powder could be attributed to its high content of certain oxygenated compounds with lipophilic properties that enable them to dissolve the cytoplasmic membrane of nematode cells and their functional groups interfering with the enzyme protein structure (Konstantopoulou et al.,1994). Apparently, our data suggest that the combination of Moringa extracts with either bioproduct BioNematon (P.lilacinum) or Gold $S$. avermitilis gave better results than did a single one (Table 1). Moreover, the present findings demonstrate that the combination of Moringa extracts with BioNematon or Gold plays a synergistic effect on minimizing M.incognita on eggplant (Table 2).

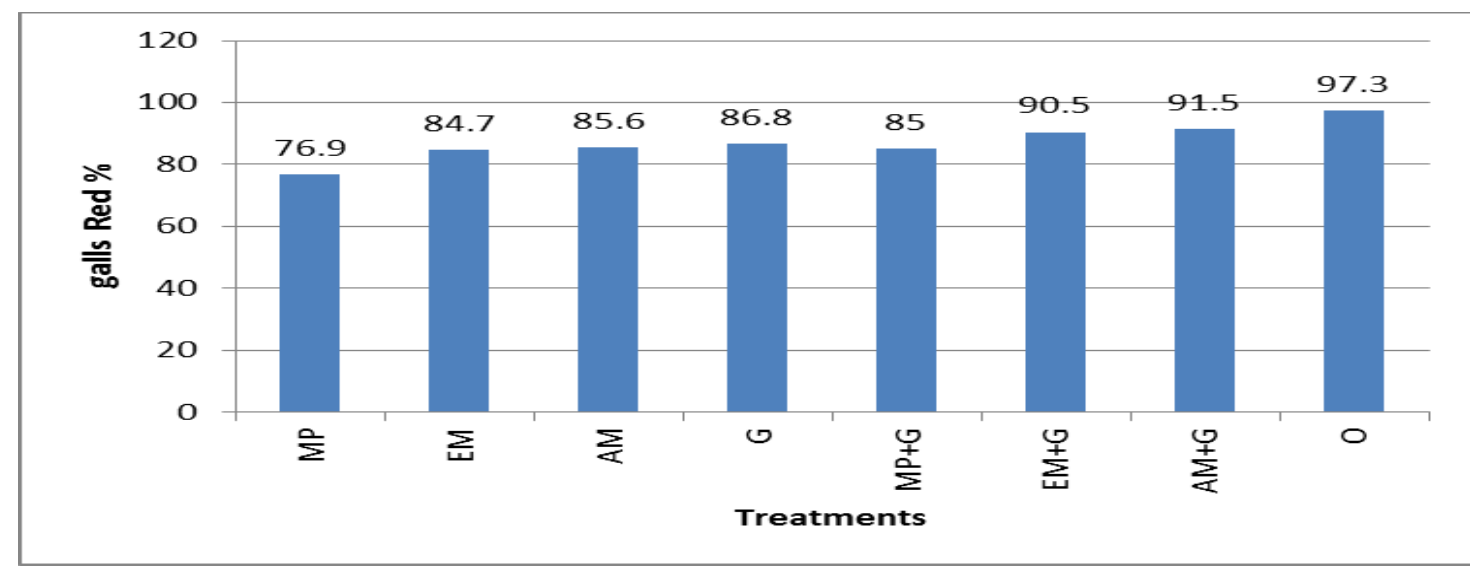

Fig.1: Reduction percentage in the number of galls of Meloidogyne incognita infecting eggplant as influenced by the addition of Moringa extracts and Abamectin.

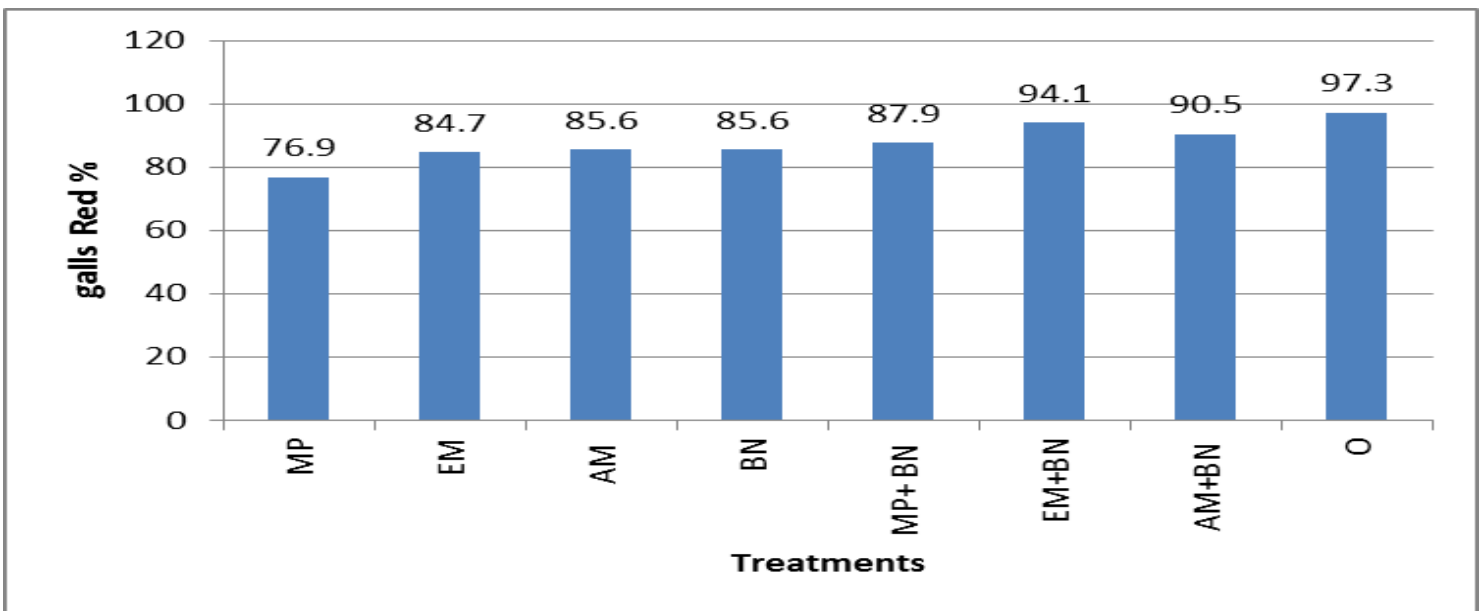

Fig.2: Reduction percentage in the number of galls of Meloidogyne incognita infecting eggplant as influenced by the addition of Moringa leaf extract and BioNematon.

$\mathrm{MP}=$ Moringa leaf powder $\mathrm{EM}=$ Ethanolic extract of Moringa $\mathrm{AM}=$ Aqueous extract of Moringa $\mathrm{BN}=$ BioNematon $\mathrm{O}=$. Oxamyl

Co-application of such bioagents significantly $(\mathrm{P}>0.05)$ suppressed $M$. incognita population, root galling, number of females and egg masses and reproduction factor. The highest reduction in total nematode population and reproduction factor was 
performed with the combination of ethanolic extract of Moringa (EM) and Gold or BioNematon. Next to Oxamyl (97.3\%) root galling was significantly suppressed with $\mathrm{EM}+$ BioNematon (94.1\%) (Fig.1) and AM+Gold (91.5\%) (Fig.2.). However, significant difference in root galling in most treatments was not detected. Females fecundity in terms of the number of egg masses and the number of eggs/single egg mass was significantly $(\mathrm{P}<0.05)$ reduced by all treatments compared to untreated plants. Previous studies revealed that combination of biocontrol agents provides effective control of root-knot nematodes in pot and field experiments (Ashraf and Khan,2008; Murslain et al., 2013 \& 2014; Udo et al., 2014; El Deriny, 2016). The invasion and development of $M$. javanica on eggplant were greatly affected with standard concentration of combined application of M.oleifera and Trichoderma harzianum (Murslain et al., 2013). Meanwhile, Udo et al. (2014) reported that double inoculation with $P$. lilacinus in combination with Lantana camara leaf extract changed the susceptibility of the tomato cultivar and was the most effective treatment in gall and egg mass inhibition, growth enhancement and dry matter accumulation.

Chemical analysis of Moringa plant extracts (Ethanolic and Aqueous leaf extracts) indicated the presence of the active ingredients i.e. flavonoids, saponins, glycosides, phenols and tannins (Table 3) that exerted nematicidal activities (Ntalli et al., 2009; Ohri and Pannu, 2010; Nguyen et al., 2013). Extraction with distilled water showed better performance in such constituents than with ethanol. This finding is on a par with results of other researchers (Mittal et al., 2007; Isitua et al., 2015).

Table 3: Phytochemical constituents in leaf extracts of Moringa oleifera.

\begin{tabular}{llllll}
\hline Solvents & Flavonoids & Saponins & Glycosides & Tannins & Phenols \\
& & & & & \\
\hline Ethanol & ++ & + & +++ & + & + \\
\hline Distilled Water & ++ & +++ & +++ & ++ & ++ \\
\hline
\end{tabular}

*Key: +++, Highly present; ++, Moderately present; +, Slightly present; -Not present

Moringa extracts showed greater performance in glycosides. Saponins are a large group of glycosidic secondary metabolites produced by many plant species and were more detected in aqueous leaf extracts of Moringa than stem or root extracts (Khairy, 2016). Herein, saponins were highly present in aqueous leaf extract of M.oleifera. Saponins have been found effective in vitro against Xiphinema index, M.incognita and Globodera rostochiensis (D'Addabbo et al., 2010). Whereas, tannins, phenols and flavonoids were moderately present in aqueous leaf extract (Table 3). Phenolic compounds may serve as defense compounds against plant pathogens and number of them have shown strong nematicidal activity (Ohri and Pannu, 2010).

The application of vermicompost as organic fertilizer rich in NPK and micronutrients has been reported to significantly suppress plant-parasitic nematodes (Ramakrishnan and Mahadevaswamy, 2011; Hemmati and Saeedizadeh, 2019; AwadAllah and Khalil, 2019) and as an excellent promoter and protector for crop plants (Chauhan and Singh, 2015). In the present study, vermicompost derived from municipal wastes enhanced plant growth attributes in terms of shoot length $(18.5 \%)$, total plant fresh weight $(32.8 \%)$ (Table 4$)$ and significantly reduced $(\mathrm{p} \leq 0.05)$ nematode population ( 64.9\%) and root galling (82.5\%) (Fig.3) compared to untreated 
Table 4: Combined effect of vermicompost and Gold (Abamectin) or BioNematon on the growth of eggplant infected with Meloidogyne incognita .

\begin{tabular}{|c|c|c|c|c|c|c|c|c|}
\hline \multirow[b]{2}{*}{ Treatments } & \multicolumn{8}{|c|}{ Plant Growth Response } \\
\hline & $\begin{array}{c}\text { Shoot } \\
\text { Length }(\mathrm{cm})\end{array}$ & $\begin{array}{l}\text { Plant } \\
\text { Length } \\
(\mathrm{cm})\end{array}$ & Inc. $\%$ & $\begin{array}{l}\text { Shoot } \\
\text { Fresh } \\
\text { weight } \\
(\mathrm{g})\end{array}$ & $\begin{array}{c}\text { Plant } \\
\text { Fresh } \\
\text { weight } \\
\text { (g) }\end{array}$ & Inc. $\%$ & $\begin{array}{l}\text { Shoot. } \\
\text { Dry.wt } \\
(\mathrm{g})\end{array}$ & Inc. $\%$ \\
\hline $\mathrm{VC}$ & $24.3 \mathrm{a}-\mathrm{c}$ & 38.3 & 8.5 & $6.4 \mathrm{ab}$ & 8.9 & 32.8 & $1.3 \mathrm{a}-\mathrm{c}$ & 18.2 \\
\hline $\mathrm{G}$ & $23.7 b-d$ & 39.4 & 11.6 & $6.1 \mathrm{a}-\mathrm{c}$ & 9.6 & 43.3 & $1.4 \mathrm{ab}$ & 27.3 \\
\hline $\mathrm{BN}$ & $26.0 \mathrm{ab}$ & 42.3 & 19.8 & $6.6 \mathrm{ab}$ & 10.6 & 58.2 & $1.4 \mathrm{ab}$ & 27.3 \\
\hline $\mathrm{VC}+\mathrm{G}$ & $23.3 b-d$ & 37.8 & 7.1 & $6.7 \mathrm{a}$ & 10.7 & 59.7 & $1.3 \mathrm{a}-\mathrm{c}$ & 18.2 \\
\hline $\mathrm{VC}+\mathrm{BN}$ & $22.7 b-d$ & 39.0 & 10.5 & $5.7 \mathrm{a}-\mathrm{c}$ & 9.8 & 46.3 & $1.2 \mathrm{bc}$ & 9.1 \\
\hline $\mathrm{O}$ & $22.3 \mathrm{~cd}$ & 36.8 & 4.2 & $3.8 \mathrm{c}$ & 8.4 & 25.4 & $1.3 \mathrm{a}-\mathrm{c}$ & 18.2 \\
\hline Healthy Plants & $27.7 \mathrm{a}$ & 45.0 & 27.5 & $7.5 \mathrm{a}$ & 11.1 & 65.7 & $1.5 \mathrm{a}$ & 36.4 \\
\hline Nematode only(N) & $20.5 \mathrm{~d}$ & 35.3 & --- & $4.2 \mathrm{bc}$ & 6.7 & --- & $1.1 \mathrm{c}$ & -- \\
\hline
\end{tabular}

Table 5: Combined effect of vermicompost and Gold (Abamectin) or BioNematon on Meloidogyne incognita population and reproduction on eggplant.

\begin{tabular}{|c|c|c|c|c|c|c|c|c|}
\hline \multirow[t]{3}{*}{ Treatments } & \multicolumn{3}{|c|}{ Nematode population in } & \multirow{3}{*}{$\begin{array}{c}\text { Total } \\
\text { nematode } \\
\text { population }\end{array}$} & \multirow[t]{3}{*}{ Red\% } & \multirow[t]{3}{*}{$\mathrm{Rf}^{*}$} & \multirow{3}{*}{$\begin{array}{l}\text { No. of } \\
\text { galls }\end{array}$} & \multirow[t]{3}{*}{ RGI** } \\
\hline & \multicolumn{2}{|c|}{ Root } & \multirow[t]{2}{*}{ Soil } & & & & & \\
\hline & D.S & Females & & & & & & \\
\hline $\mathrm{VC}$ & $2.7 b$ & $7.7 b$ & $1018.4 b$ & 1028.8 & 64.9 & 0.7 & $9.7 b$ & 2.3 \\
\hline G & $2.3 b$ & $5.3 b$ & $820.0 \mathrm{bc}$ & 827.6 & 71.8 & 0.6 & $7.3 b$ & 2.3 \\
\hline $\mathrm{BN}$ & $2.3 b$ & $6.7 b$ & $718.3 \mathrm{bc}$ & 727.3 & 75.2 & 0.5 & $8.0 \mathrm{~b}$ & 2.3 \\
\hline $\mathrm{VC}+\mathrm{G}$ & $2.6 b$ & $5.3 b$ & $685.0 \mathrm{bc}$ & 692.9 & 76.3 & 0.5 & $7.7 \mathrm{~b}$ & 2.3 \\
\hline $\mathrm{VC}+\mathrm{BN}$ & $3.7 b$ & $5.3 b$ & $591.7 b-d$ & 600.7 & 79.5 & 0.4 & $8.0 \mathrm{~b}$ & 2.3 \\
\hline $\mathrm{O}$ & $2.3 b$ & $1.3 b$ & $348.8 \mathrm{~cd}$ & 352.4 & 88.0 & 0.2 & $1.5 b$ & 1.0 \\
\hline Nematode only(N) & $18.0 \mathrm{a}$ & $40.0 \mathrm{a}$ & $2875.0 \mathrm{a}$ & 2933.0 & --- & 2.0 & $55.5 \mathrm{a}$ & 2.8 \\
\hline $\begin{array}{l}\text { Each value is the me } \\
\mathrm{BN}=\text { BioNematon } P l\end{array}$ & $\begin{array}{l}\text { of fo } \\
\text { ireoc }\end{array}$ & $\begin{array}{l}\text { plicates } \\
\text { n lilacin }\end{array}$ & $\begin{array}{l}\mathrm{C}=\text { Verm } \\
\mathrm{O}=. \text { Oxa }\end{array}$ & $\begin{array}{r}\text { post ; G= } \\
\mathrm{N}=1500\end{array}$ & $\begin{array}{l}(\mathrm{Ab} \\
\text { of } M\end{array}$ & $\begin{array}{l}\text { A, Str } \\
\text { nita. }\end{array}$ & myces c & mitilis); \\
\hline
\end{tabular}




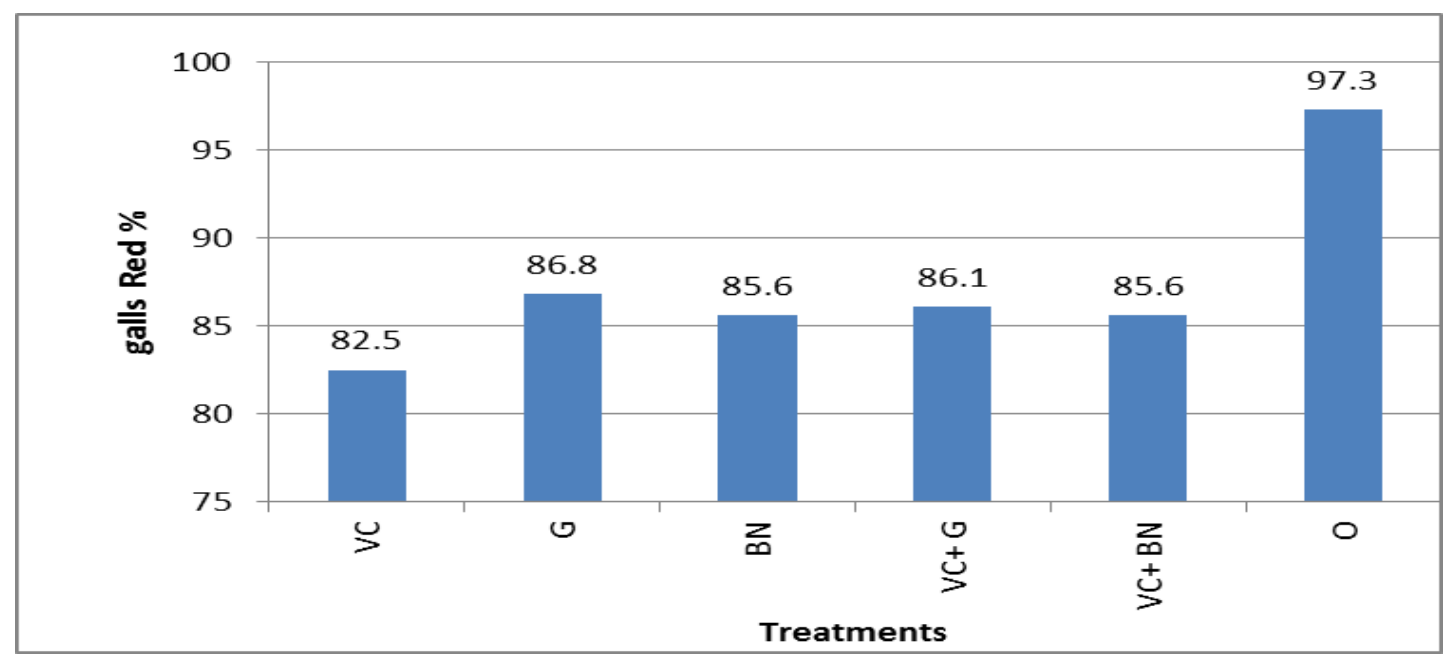

Fig3: Reduction percentage in the number of galls of Meloidogyne incognita infecting eggplant as influenced by the addition of vermicompost, BioNematon and Abamectin.

$\mathrm{VC}=$ Vermicompost, $\mathrm{G}=$ Gold (Abamectin), $\mathrm{BN}=$ BioNematon, , O=.Oxamyl

plants (Table 5). Both Abamectin and BioNematon surpassed vermicompost in promoting total plant fresh weight, however a synergistic effect on such criterion was recorded with the combinations of vermicompost and Abamectin (Table 4). The suppression of $M$. incognita population and reproduction on eggplant by P.lilacinum or Abamectin S.avermitilis was increased with the addition of vermicompost even no significant differences were noticed (Table 5).Females fecundity in terms of the number of egg masses and the number of eggs/single egg mass was significantly $(\mathrm{P}<0.05)$ reduced by all treatments. According to Arya $(2016)$ reports combined inoculations of $T$. harzianum and vermicompost proved effective in reducing infection of $M$. incognita and increasing the germination percentage of tomato. Many mechanisms can be involved in the suppression of vermicompost such as decomposition into the soil and ammonia production stimulation of soil microbial biomass and release of biocidal substances that have nematicidal activity (Oka \& Yermiyahu, 2002). Nematodes can also be killed by toxic substances such as hydrogen sulfide, ammonia, and nitrites released during vermicompost degradation in the soil (Rodriguez-Kábana, 1986).

Chemical analysis of the studied vermicompost revealed an excess of ammonium (67 ppm), nitrate (179 ppm) and low $\mathrm{C} / \mathrm{N}$ ratio 1:14.(Mohamed et al., 2019). Higher availability of nitrogen enhances the nematicidal activity of manures against plant-parasitic nematodes (Mian and Rodriguez-Kábana 1982). So, materials with lower $\mathrm{C}$ : $\mathrm{N}$ ratios are more nematicidal than those with higher ratios (Ismail et al. 2006; Renčo et al. 2011).

In conclusion, our results suggested that the addition of Moringa extracts or vermicompost, with BioNematon or Abamectin provided significant effective control against $M$. incognita infecting eggplant. However, no significant differences were demonstrated compared to Oxamyl. Because of the high price of nematicides and synthetic fertilizers, the uses of Moringa extracts or vermicompost as organic fertilizers combined with biopesticides are thus promising for the control of root-knot 
nematodes in sustainable agricultural systems and offer cheap and safe nematicidal alternatives. However, further studies are required using Moringa extractives and vermicompost integrated with one or two bioagents with different mechanisms for the management of root-knot nematodes under greenhouse and field conditions.

\section{REFERENCES}

Arancon,N.Q. ;Edwards, C.A.; Bierman, P.; Metzger, J.D. and Lucht, C. (2005). Effects of vermicomposts produced from cattle manure, food waste and paper waste on the growth and yield of peppers in the field. Pedobiologia 49(6):297306. DOI:10.1016/j. pedobi.02.001.

Arya,R. (2016). Combined effect of Trichoderma harzianum and vermicompost in the management of root knot nematode (Meloidogyne incognita) in tomato $\mathrm{cv}$ Pusa Ruby. Indian Phytopath. 69 (4s): 464-467.

Ashraf,M.S. and Khan,T.A.(2008). Biomanagement of reniform nematode, Rotylenchulus reniformis by fruit wastes and Paecilomyces lilacinus on chickpea. World J. Agric. Sci.4(4):492-494.

Awad-Allah, S.F.A. and Khalil, M.S.(2019). Effects of vermicompost, vermicompost tea and a bacterial bioagent against Meloidogyne incognita on banana in Egypt. Pakistan J. Nematol. 37 (1):25-33. DOI: 10.18681/pjn.v37.i01.p25-33

Azam, S .; Samiullah, T.R .; Yasmeen, A .; Din, S .; Iqbal1, Qayyum, A. A .;Rao,A.; Nasir, I.; Rashid, B.; Shahid,A.A.; Ahmad, M. and Husnain,T.(2013). Dissemination of Bt cotton in cotton growing belt of Pakistan. Adv. Life Sci. $1(1): 1-10$.

Byrd,D.W.; Kirkpatrick, T. and Barker,K .(1983). An improved technique for clearing and staining plant tissues for detection nematodes. J Nematol, 15 (3): 142-143.

Cardona, B.N.L. and Leguizamon, C.J.E. (1997). Isolation and pathogencity of fungi and bacteria to the root-knot nematode of coffee Meloidogyne spp. Goldi. Fitopato. Colombena 2(1): 39-52.

Chauhan, H.K. and Singh, K. (2015). Potancy of vermiwash with neem plant parts on the infestation of Earias vittella (Fabricius) and productivity of okra (Abelmoschus esculentus) (L.) Moench. Asian J. Res. Pharm. Sci. 5(1):36-40. DOI: $10.5958 / 2231-5659.2015 .00006 .5$

Claudius-Cole, A. O.; Aminu, A. E. and Fawole, B. (2010). Evaluation of plant extracts in the management of root-knot nematode Meloidogyne incognita on cowpea [Vigna unguiculata (L) Walp]. Mycopathology 8(2):53-60.

D'Addabbo,T.; Laquale, S.; Perniola,M. and Candido ,V.(2019). Biostimulants for plant growth promotion and sustainable management of phytoparasitic nematodes in vegetable crops. Agronomy 9 (10): 110. DOI. Org/10.3390/ agronomy 9100616

Devi,J. and Prakash, M. (2015). Microbial population dynamics during vermicomposting of three different substrates amended with cowdung. Int. J. Curr. Microbiol. Appl. Sci. 4(2):1086-1092.

Duncan, D.B. (1955). Multiple range and multiple, F-test. Biometrics, 11: 1-42.

El-Deriny, M.(2016).Integrated control of certain plant parasitic nematodes infecting cucurbitaceae plants. Ph.D. Thesis, Fac. Agric. Mansoura Univ. Mansoura, Egypt. pp.154.

El-Deriny,M.M.; Ibrahim, D.S.S. and Mostafa, F.A.M .(2020). Organic Additives and Their Role in the Phytoparasitic Nematodes Management in Management 
of Phytonematodes: Recent Advances and Future Challenges,73-93. DOI: 10.1007/978-981-15-4087-5

FAOSTAT (2019). Eggplant production in 2018, Crops/Regions/World list/Production Quantity.https://en.wikipedia.org/wiki/Eggplant.

Gabour, E.I.; Marahatta, S.P. and Lau, J.W.(2015). Vermicomposting: A potential management approach for the reniform nematode, Rotylenchulus reniformis. Nematropica, 45(1): 285-287.

Ganaie,M.A.(2018). Paecilomyces lilacinus an efficient bionematicide. Int. Conference Sci, Technol \& Management. 94(8):32-36.

Goodey,J.B.(1957).Laboratory methods for work with plant and soil nematodes.Tech.Bull.No. 2. Min. Agric. Fish Ed. London,47 pp.

Hussain,M.A.; Fatima,I.; Mukhtar ,T.; Aslam,M.N. and Kayani,M.Z. (2015). Effect of inoculum density of root-knot nematode Meloidogyne incognita on damage potential in eggplant. Mycopath, 13(1):33-36

Hemmati, S. and Saeedizadeh, A. (2019).Root-knot nematode, Meloidogyne javanica, in response to soil fertilization. Braz. J.Biol. Ahead of Print:1-10. DOI.org/10.1590/1519-6984.218195.

Isitua,C.C.; Lozano,M.J.S.; Jaramillo,C.J. and Dutan, F.(2015). Phytochemical and nutritional properties of dried leaf powder of Moringa oleifera Lam. from machala el oro province of ecuador. Asian J. Plant Sci. Res. 5(2):816.DOI:10.4172/2161-0495. S1. 013.

Ismail, A. E., Rawia, A. E and El-Nagdi, W. M. A. (2006). Effect of different composts, biofertilizers and olive pomace as soil amendments on Rotylenchulus reniformis, growth and chemical analysis of jasmine. Egypt. J. Appl. Sci. Res. 2(11): 909 - 919.

Ismail, A. E. (2013). Feasibility of growing Moringa oleifera as a mix-crop along with tomato for control of Meloidogyne incognita and Rotylenchulus reniformis in Egypt. Arch. Phytopathol. Plant Protect.46(12):1403-1407. DOI. org/ 10.1080 /03235408. 2013. 768062

Khairy,D.M. (2016). Management of root-knot nematode Meloidogyne incognita by the use of certain bioagents. M.Sc. Thesis , Fac. Agric., Mansoura Univ.Egypt.pp. 110.

Khalil, M.S.(2013). Abamectin and azadirachtin as eco-friendly promising biorational tools in integrated nematodes management programs. Plant Pathol. Microbiol. 4(4):1-7. DOI:10.4172/2157-7471. 1000174.

Khan, A.; Williams, K.L. and Nevalainen, H.K. (2006). Infection of plant-parasitic nematodes by Paecilomyces lilacinus and Monacrosporium lysipagum. BioControl 51: 659-678.

Konstantopoulou, I.; Vassilopoulou ,L.; Mawogantisi ,P.P. and Scouras, G.(1994). Insecticidal effect of essential oils: a study of essential oils extracted from eleven Greek aromatic plants on Drosophila auroria. Experientia. 48:616619.

Mahmood,I. and Saxena, S.K.(1992). Effect of green manuring with certain legumes on the control of plant parasitic nematodes. Pakistan J.Nematol, 10: 139-143.

Mainoo,A.A. and Banful,B.K. (2019).Nematicidal properties of Moringa oleifera, Chromolaena odorata and Panicum maximum and their control effects on pathogenic nematodes of yam, J. Exp. Agric Int.31(2): 1-7. DOI: 10.9734/ jeai/v31i230066. 
Makkar, H.P.S. and Becker ,K. (1996). Nutritional value and anti- Moringa oleifera nutritional components of whole and ethanol extracted leaves. Anim. Feed. Sci. Technol. 63:211-228. DOI.org/10.1016/S0377-8401(96)01023-1.

Metwally, W. E.; Ashraf, E. K. and Mostafa,F.A.M.(2019). Biopesticides as ecofriendly alternatives for the management of root-knot nematode, Meloidogyne incognita on cowpea (Vigna unguiculata L.). Egypt. J. Agronematol. 18(2): 129-145. DOI: 10.21608/ejaj.2019.51846.

Meyer, L.H.(2003).Prejudice, social stress, and mental health in lesbian , gay, and bisexual population: Conceptual issues and research evidence, Psychol. Bulletin 129(5):674-697.

Mian, H. and Rodriguez-Kabana, R. (1982 ). Survey of the nematicidal properties of some organic materials available in Alabama as amendments to soil for control of Meloidogyne arenaria. Nematropica 12: 235-246.

Mittal, L.; Mittal, P.and Agarwal A.C.(2007). Pharmacognostical and phytochemical investigation of antidiabetic activity of Moringa oleifera lam leaf. The Indian Pharmacist 6 (59):70-72

Murslain, M.; Javed,N.; Khan,S.A.; Khan,H.U.; Abbas, H. and Munawar,M. (2013).Efficacy of Moringa leaves and Trichoderma harzianum on the invasion and development of Meloidogyne javanica. Pakistan J. Phytopathol. 25(1):59-64.

Murslain, M.;Javed,N.; Khan, S.A.;Khan, H.U.;Abbas,H. and Kamran, M.(2014). Combined efficacy of Moringa oleifera leaves and a fungus, Trichoderma harzianum against Meloidogyne javanica on eggplant. Pakistan J. Zool. 46(3):827-832.

Mohamed, A. S.; Ayman, A.M. A. and Ibrahim, Dina, S.S.(2019). Potential of vermicompost and vermicompost tea to improve yield and quality of kalamata olive trees infected with root-knot nematode, Meloidogyne incognita. World J.Agric. Sci., 15 (6): 414-424. DOI: 10.5829/idosi.wjas.414.424

Nguyen,D.M.C.;Seo,D.J.;Kim,K.Y.;Park,R.D.;Kim,D.H.;Han,Y.S.;Kim,TH.and Jung, W.J.(2013). Nematicidal activity of 3,4 dihydroxybenzoic acid purified from Teminalia nigrovenulosa bark against Meloidogyne incognita. Microb. Pathol.59(60):52-59.

Ntalli,N.G.; Menkissoglu-Spiroudi,U.;Giannakou,I.O. and Prpphetou-Athanasiadou, D.A.(2009). Efficacy evaluation of neem (Azadirachta indica A. Juss) formulation against root- knot nematode, Meloidogyne incognita. J. Crop Prot.28: 489 -494. DOI.org/10.1016/j.cropro.01.011

Oclarit. E. L and Cumagun, C.J.R. (2009). Evaluation of efficacy of P. lilacinus as biological control agent of Meloidogyne incognita attacking tomato. J. Plant Prot.Res. 49 (4):337-340. DOI.10.2478/v10045-009-0053-x.

Ohri, P. and Pannu, S.K.(2010). Effect of phenolic compounds on nematodes: a review. J. Appl.Natio.Sci. 2: 344-350. DOI.org/10.31018/jans.v2i2.144

Oka,Y. and Yermiyahu, U. (2002). Suppressive effects of composts against root-knot nematode Meloidogyne javanica on tomato. J. Nematol. 4(8):891-898. DOI. org/10.1163/156854102321122502.

Olajide, M.C.;Izuogu, N.B.; Apalowo,R.A. and Baba,H.S .(2018). Evaluation of the nematicidal and antifungal activity of aqueous extracts of Moringa oleifera leaves and seed in cucumber field. Cercetări Agronomice în Moldova, 4 (176): 47-59. DOI. org/ 10.2478/cerce-2018-0035 
Pura,H. and Matiyar R. K .(2016).Evaluation of fungal (Paecilomyces lilacinus) formulations against root-knot nematode infecting tomato. Bangladesh J. Bot. 45(5):1003-1013.

Pathma, J. and Sakthivel, N. (2012). Microbial diversity of vermicompost bacteria that exhibit useful agricultural traits and waste management potential, Springer Plus 1(26): 1-19. doi: 10.1186/2193-1801-1-26.

Ramakrishnan, S and Mahadevaswamy, M. (2011). Efficacy of vermicompost against root-knot nematode in Flue Cured Virginia (FCV) tobacco. Indian J. Nematol, 41(2): 210-212.

Renčo, M.; Sasanelli, N.and Kováčik, P. (2011).The effect of soil compost treatments on potato cyst nematodes Globodera rostochiensis and Globodera pallida. Helminthologia,3:184-194. DOI. 10.2478/s11687-011-0027-1.

Rodriguez-Kabana,R .(1986). Organic and inorganic nitrogen amendments to soil as nematode suppressants. J. Nematol. 18, 129-135.

Sasanelli, N.; Toderas, I.; Veronico, P.; Iurcu-Straistaru, E.; Rusu,S .; Melillo, M T. and Caboni, P. (2019). Abamectin efficacy on the potato cyst nematode Globodera pallida. Plants (Basel), 9(1):1-12. DOI: 10.3390/plants9010012.

Singh, A.U. and Prasad, D. (2014). Management of plant-parasitic nematodes by the use of botanicals. J. Plant Physiol.Pathol. 2(1): 1-10.

Sowley, E. N. K .; Kankam, F. and Dasmana, H .(2018). Effect of time of application of moringa (Moringa oleifera L.) leaf powder on root-knot nematode (Meloidogyne spp.) infecting cowpea (Vigna unguiculata L. walp). Adv. Agric.Sci. 6 (4): 32-41 .

Sowley, E.N.K.; Kankama,F. and Adomakob,J.(2013). Management of root-knot nematode (Meloidogyne spp.) on sweet pepper (Capsicum annuum L.) with moringa (Moringa oleifera Lam.) leaf powder. Arch. Phytopathol. Plant Protect.1-8.

Taylor, A. L. and Sasser, J. N. (1978). Biology, identification and control of root-knot nematodes (Meloidogyne species). Raleigh, NC: North Carolina State University Graphics.

Udo, I.A.; Osai, E.O. and Ukeh,D.A.(2014). Management of root-knot disease on tomato with bioformulated Paecilomyces lilacinus and leaf extract of Lantana camara. Brazilian Arch. Biol. Tech. 57(4) : 486-492. DOI.org/10.1590/S151689132014005000022

Youssef, M.M.A. and Lashein, A. M.S. (2015). Effect of some commercial biofertilizers and a biocide on root knot nematode, Meloidogyne incognita infesting date Palm in a newly reclaimed soil in Egypt, Middle East J. Appl. Sci.5(1) : 143-147.

Youssef, M.M.A.; El-Nagdi,W.M.A. and Eissa, M.F.M.(2014). Population density of root knot nematode, Meloidogyne incognita infecting date palm under stress of aqueous extracts of some botanicals and a commercial bacterial byproduct, Middle East J. Appl.Sci. 4(4): 802-805. 


\title{
الملخص العربى
}

\section{مكافحة نيماتودا تعقد الجذور التى تصيب نبات الباذنجان \\ باستخدام مستخلصات المورينجا، فيرميكمبوست واثنان من المركبات التجارية الحيوية}

\author{
دعاء خيرى -عبد الفتاح رجب رفاعى ـ فاطمة عبد المحسن مصطقى \\ قسم الحيو ان الزر اعى ـكلية الزر اعة- جامعة المنصورة ـ مصر
}

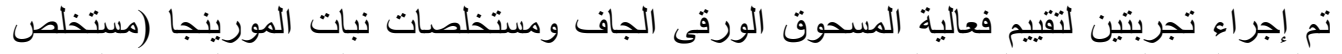
الإيثانول ، المستخلص المائى) او السماد العضوي (vermicompost) مع اثنان من المنتجات التجارية الحيوية Streptomyces) Abamectin Gold1.8\% و(Purpureocillium lilacinum) BioNematon (avermitilis

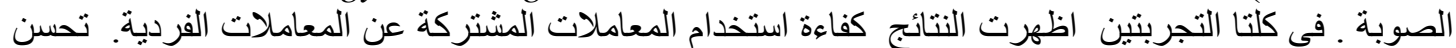

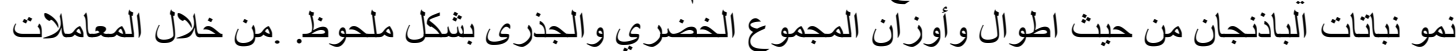

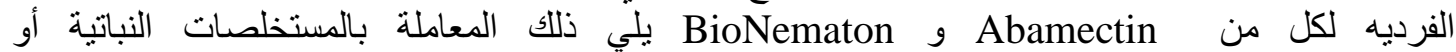

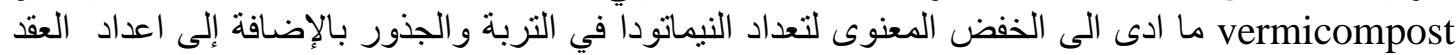

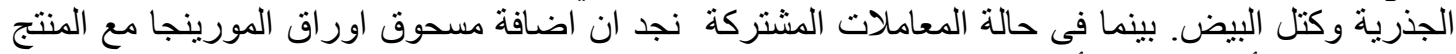

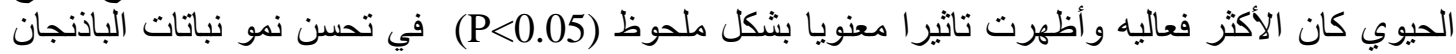
وخض تعداد النيماتو دا في التربة و الجذور وكذللك اعداد العقد وكتل البيض مع عدم تسجيل فروق معني معنوية مقارنة بالأوكساميل.

أظهرت المعامله C/N نسبة C/N نسخفضة (1:14) مع زيادة النيتروجين التي تسبيت

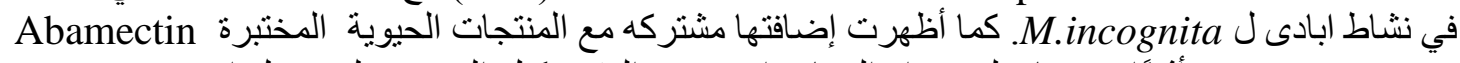

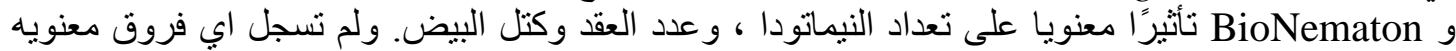

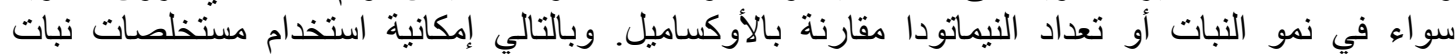

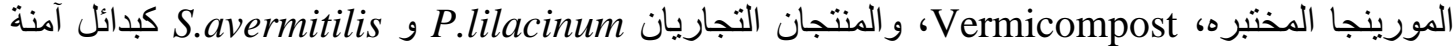
لمكافحة M.incognita التي تصيب نباتات الباذنجان ضمن برنامج مكافحه منكاملة وتحقبق التنمية المستدامة. 